\title{
Siyasal Kampanyaların Geleceğinde Veri Temelli Yönelimler
}

\section{Burcu ZEYBEK'}

\begin{abstract}
Öz
Siyasal kampanya çalışmalarının evrim geçirmeye devam edeceğini, pazarlama ve reklam teknolojisinde geliştirilen en son tekniklerden yararlanacağını varsaymak için yeterli neden bulunmaktadır. Siyasal kampanyalara ayrılan bütçeler, bu varsayımı desteklemektedir. Bu çalışmada veri temelli yönelimlerin siyasal kampanyalarda mevcut ve potansiyel kullanımını ortaya koymak amaçlanmıştır. Bu yönelimlerin pek çoğu hâlâ gelişmekte olduğundan, çalışma, verilerin günümüzde nasıl kullanıldıklarından örneklerle, bazılarının önümüzdeki yıllarda nasıl uygulanabilecekleri ile ilgili incelemelerden oluşan betimleyici bir çalışmadır. İncelemenin tamamında mevcut kullanımlar ile olası kullanımlar birbirinden ayrılmaktadır. Ayrıca bu yeni teknolojilerin ne ölçüde etkili olacakları ile ilgili çıkarımda bulunmamakla birlikte, veri analizlerinin siyasal kampanyalarda nasıl kullanılmakta olduğuna ve bunun gelecekte nasıl gelişebileceğine bakılmıştır. Çalışma -kötü niyetli aktörlerin değil- meşru siyasi partilerin yararlanma yoluna gidebileceği yasal yöntemlerle sınırlandırılmıştır.
\end{abstract}

Anahtar Kelimeler: Siyasal Kampanya, Veri Analizi, Yapay Zekâ.

Atıf: Zeybek, B. (2020). Siyasal Kampanyaların Geleceğinde Veri Temelli Yönelimler. Akdeniz Üniversitesi Illetișim Fakültesi Dergisi, 33, s. 54-72

1 Dr. Öğr. Üyesi, Doğuş Üniversitesi, Halkla İlişkiler ve Tanıtım Programı. bzeybek@dogus.edu.tr, ORCıD Numarası: 0000-0002-2391-5727. 


\title{
Data-Based Trends in the Future of Political Campaigns
}

\begin{abstract}
There is sufficient evidence to assume that political campaign studies will continue to evolve and utilize the latest techniques, developed in marketing and advertising technologies. Allocated to political campaigns, the budgets support this assumption. This study aims to reveal current and potential usage of data-based orientations in political campaigns. To that end, the study is a descriptive study of examinations of how some of the data can be utilized in upcoming years, rather than how it is currently used, for the majority of the orientations in question are still developing.. Current utilizations and potential utilizations differ from each other throughout the analyses. Furthermore, the manners, in which data analyses are used in political campaigns, and how they can be improved in future are checked, while the degree to which these novel technologies would be effective was not judged. The limitation of the study is represented by legal methods that legitimate and lawful political parties might adopt - and not those from malicious actors.
\end{abstract}

Keywords: Political Campaign, Data Analysis, Artificial Intelligence

\section{Giriș}

$\mathrm{R}$ eklam ve pazarlama tekniklerinin veri analistlerinden oluşan bir ağ tarafından hedef kitle segmentasyonu ve dünyanın dört bir noktasındaki siyasal partileri hedeflemek amacıyla sunulmasıyla birlikte, seçimler gittikçe daha fazla 'verileşmektedir'. Bu tekniklerin büyük bir kısmı ilk olarak ticaret sektöründe geliştirilmiştir. Chester ve Montgomery'nin (2017) çalışmasında da belirttikleri gibi, 'seçim politikaları artık gittikçe büyüyen, küresel ticari dijital medya ve pazarlama ekosistemi ile bütünüyle entegre hale gelmektedir. Bu ekosistem, şirketlerin ürünlerini pazarlama ve müşterileri etkileme biçimlerini hali hazırda dönüştürmüştür.

Ingiltere deki siyasal partiler, seçmenleri daha etkin bir şekilde hedefleyebilmek için yukarıda belirtilen veri yönetimi yaklaşımlarını uygulayarak veri yeteneğine yatırım yapmaya başlamıştır (Windsor ve Murphy, 2014). Iş̧̧i Partisi NationBuilder'ı kullanırken, Liberal Demokratlar, Birleşik Devletlerdeki Demokrat Partinin seçmen sayısını artırmak için başvurduğu NGP VAN adlı platformu tercih etmiştir. Bu yazılım platformları, siyasal partilerin belli bir seçim bölgesindeki bireylere yönelip, daha fazla hedefe dönük mesajlar iletmelerine olanak sağlamaktadır (Steward, 2017).

Donald Trump'ın 2016 yılı Amerika Birleşik Devletleri başkanlık seçimleri sırasında yürüttüğü kampanya, büyük veri analizlerinden yararlanması dolayısıyla medyada çok fazla yer bulurken, son yıllarda yürütülen çok sayıda kampanyada benzer yaklaşımlardan yararlanılmaktadır. Dominic Cummings, Birleşik Krallık'ta düzenlenen Avrupa Birliği Referandumu sırasında, seçim öncesinde çoğunluğu Facebook üzerinden yayınlanan ayrılma yanlısı reklam mesajlarının bir milyar kadar kişiye ulaştığını belirtmektedir. Trump'ın kampanyasında olduğu gibi reklamcılar, mesajların farklı versiyonlarını gön- 
dererek, onları interaktif bir geri bildirim döngüsünde test etmiştir (Cadwalladr, 2017). 2017 İngiltere genel seçimlerinde İşçi Partisi, potansiyel İşçi Partisi seçmenlerini tespit etmek için veri modellemesinden yararlanmış ve sonrasında mesajlarla bu potansiyel seçmenleri hedef almıştır (Waterson, 2017). Deneyimli Emek Partisi aktivistleri, Facebook bilgilerini Emek Partisi seçmen verileri ile bir araya getiren 'Promote' adında bir kurum içi uygulamadan yararlanarak, yerel tabanlı mesajları doğru (ikna edilebilir) kişilere gönderebilmiştir. Dünyanın dört bir noktasındaki diğer ülkelerden bunlara benzer çok sayıda örnek mevcuttur (Steward, 2017; Constine, 2016).

Siyasal kampanya çalışmalarının evrim geçirmeye devam edeceğini ve pazarlama ve reklam teknolojisinde geliştirilen en son tekniklerden yararlanacağını varsaymak için önümüzde yeterli neden vardır. Siyasal kampanyalara ayrılan bütçeler, bu iddiayı desteklemektedir. Dijital harcamaların Seçim Komisyonu Tarafından ilk kez ayrı olarak raporlandığı 2015 yılında, toplam harcamanın yaklaşık \%23'ünü dijital harcamalar oluşturmuş, bu bütçenin büyük bir kısmı Facebook’a harcanmıştır (Tambini, 2018). Buradan hareketle çalışmada veri temelli yönelimlerin siyasal kampanyalarda nasıl kullanmakta olduğuna ve bunun gelecekte nasıl gelişebileceğine bakmak önemlidir.

\section{Siyasal Kampanyalarda Veri Analizlerinin Kullanımı}

Veri analizlerinin siyasal kampanyalarda kullanımı ile ilgili yedi ana tema tanımlanmıştır:

\subsection{Ayrıntılı Hedef Kitle Segmentasyonu (Detailed Audience Segmentation)}

Segmentasyon, geniş bir pazarı baz alarak belirli gruplara veya karakteristik özelliklere göre kitleleri ayırma işlemidir. Grunig ve Repper'e (2005, s.144) göre ise segmentasyon bir nüfusu, pazarı ya da izleyici kitlesini, her segmentin üyeleri birbirine diğer segmenttekilerden daha çok benzeyecek şekilde gruplara ayırmaktır. Segmentler, bir iletişim çabası tarafından hedeflenen tutum ve davranışları belirleyen değişkenlerin kalıplarına (ve bu değişkenler üzerindeki değerlere) göre homojen olmalıdır. Yani hedef kitle segmentasyonu ile geniş ve heterojen kitleler küçük gruplara ayrılarak, müşteriye bireysel istek ve ihtiyaçlarına cevap veren ürün ve hizmet sunulmaktadır. Ayrıca müşteri grupları bazında ürün önerileri oluşturulur ve pazarlama programları geliştirilmektedir (Hwang, Jung ve Suh, 2004). Kitleler coğrafi, demografik, psikografik ve davranışa dayalı özelliklerine göre gruplandırılırlar (Kotler ve Armstrong, 2001).

Coğrafi segmentasyon; pazarı şehir, bölge, ülke gibi coğrafik birimlere ayırır. Günümüzde birçok şirket; reklam, promosyon ve satış faaliyetlerini farklı özellikler gösteren coğrafik birimlerin intiyaçları ile uyumlu hale getirmeye çalışmaktadır.

Demografik segmentasyon; müşterileri yaş, cinsiyet, aile büyüklüğü, gelir, meslek, tahsil gibi kriterleri baz alarak gruplandırır.

Psikografik segmentasyon; müşterileri sosyal sınıf, yaşam tarzı ve kişilik özelliklerine dayalı olarak gruplandırır. 
Davranışa dayalı segmentasyon ise müşterileri ürünü kullanma, kendisine sunulan önerilere cevap verme, satın alma sıklığı, satın alma miktarı gibi kriterlere dayalı olarak gruplandırmaktadır.

Artan müşteri segmentasyonu, demografik veriler, davranışlar ve tutumlar hakkında ayrıntılı bilgiler temelinde müşterilerin daha küçük gruplara ayrılmasına imkân sağlamaktadır. Martin Moore ile Damian Tambini (2018) 'nin sosyal medyanın gücü ve seçimlerin meşruiyeti üzerine ortaya koydukları çalışmada veri odaklı kampanyaların üstün hedef belirleme ve hedef kitle segmentasyonu olanakları sunması, siyasal strateji ve kampanya uzmanları için özellikle ilgi çekici bir durumdur. Kampanyalar, seçimin dengesini değiştirebilecek ya da kilit seçmenlerin bulunduğu bölgelerde, kararsız fakat büyük olasılıkla oy verecek olan seçmenlere onlar için en ikna edici olduğunu düşündükleri mesajları ulaştırabilmektedir.

Seçmenlerin gittikçe daha fazla kutuplaşması, yeni ticari ürünler tarafından sunulan özelliklere yansımaktadır. Örneğin 2016 yılında, küresel reklam devi WPP'nin Xaxis sistemi, 'Xaxis Politics' uygulamasını piyasaya sürmüştür. Bu uygulama, 'tüm dijital kanallardaki tüm Birleşik Devletler seçmenlerine ulaşabildiğini' ve hedef kitleleri gerçek dünyadaki özel olaylarla bağlantılı gerçek zamanlı kampanyaların da dâhil olduğu tekniklerle, gündem oluşturan yüzlerce konu, bir partiye duyulan yakınlık gibi unsurlardan yararlanarak segmentlere ayırabildiğini iddia etmektedir (Chester ve Montgomery, 2017). Veri geliştirme alanında uzmanlaşmış L2 adlı veri şirketi ise, ulusal seçmen dosyasındaki tüm kayıtların onlarca işlem adımından geçtiği 'seçmen dosyası geliştirme' hizmeti sunmaktadır. Bu hizmetlere 'yaşam tarzı veri geliştirme uygulamaları' (gelir düzeyi, meslek, eğitim durumu, muhtemel medeni hal, etnik ve medeni kimlik, muhtemel ana dil, dergi abonelikleri, evcil hayvan sahipliği vs.) ve 'modelleme geliştirmeleri' (eş cinsel evlilikleri, bireysel silahlanmanın kontrol altına alınması ve göç gibi konular hakkında bireyler tarafından beyan edilmiş görüşler vs.) dahildir (http://www. I2political.com).

Hedef belirleme alanındaki önemli gelişmelerden biri, potansiyel destekçiler ve seçmenleri belirlemeye yönelik 'benzer modellemenin' sürekli iyileştirilmesidir. Kimi zaman 'akran grupları' ya da 'ikna edilebilir olanlar' olarak tanımlanan bu kişiler, siyasal kampanyalar yürüten uzmanların, mevcut hedef kitleleri ile benzerlikler taşıdıkları için partileri ile ilgilenmesi muhtemel olan yeni kişilere sosyal ağlar üzerinden ulaşmalarına imkân sağlamaktadır. Siyasal dünyada benzer hedef kitlelerden yararlanılması şimdiden yaygın bir uygulamadır. Facebook 'benzer hizmeti,' Trump'ın seçim kampanyasında yoğun bir şekilde kullanılmıştır ve Hollanda 2017 genel seçim kampanyaları üzerine yakın zaman önce gerçekleştirilmiş bir çalışma, 'neredeyse tüm kampanyaların yeni potansiyel seçmenleri bulmak için benzer hedef kitleler fonksiyonundan yararlandıklarını' ortaya koymaktadır (Dobber vd., 2017).

Müşteri segmentasyonu gittikçe daha fazla gelişmekte ve kullanıcı güdülenmeleri ve inançları hakkında yeni kavrayışlar sunma vaadi ile daha ayrıntılı kişi kategorileri yaratmak üzere veri kaynaklarından gittikçe daha fazla yararlanmaktadır (Machines, 2018). Bu yeni tekniklerin kısa süre sonra siyasal kampanyalarda kullanılacağı, bu kampanyalarda potansiyel seçmenler hakkında çok daha geniş kapsamlı segmentas- 
yon elde etmek üzere yapay zekâ ve öğrenme fonksiyonu ile birlikte loT (Internet of Thing-Nesnelerin İnterneti) cihazlarının daha fazla kullanıcı verisine ulaştıracağı varsayılmaktadır.

Seçmenlerin demografik profili içerisinde ikna edilmesi gereken önemli bir unsur, ‘etkileyiciler> olacaktır. Nielsen (2015) tarafından gerçekleştirilmiş araştırma, müşteriler arasında reklamın en inandırıcı biçiminin hâlâ arkadaşlar olduğunu, hem pazarlama kampanyaları hem de siyasal kampanyalarda marka mesajlarını geniş kitlelere iletmek için - görece düşük bir seviyede de olsa - anahtar etkileyicilerden yararlanmak şimdiden yaygın bir uygulama olduğunu ortaya koymaktadır. Facebook, adayların siyasi konular hakkında çok fazla paylaşım yapan kişileri kasıtlı olarak hedef almalarına imkân sağlamaktadır. Ekonomi dergisi FastCompany'ye göre siyasi etkileyiciler, 'teması siyaset olan çok sayıda sayfa gibi siyasi reklamları tıklayıp, politika gruplarından içerik paylaşan kişiler olarak' tanımlanmaktadır (Ungerliederi, 2015).

Yapay Zekâ 'markaların etkileyiciler ile çalışma biçimlerini' kaçınılmaz olarak dönüştürecektir (Yovanno, 2018). Siyasal kampanyaların bu değerli kişiler ile ilişkilerini iyileştirmek ve sonrasında potansiyel seçmenlerine ulaşmak için yapay zekânın gücünü kendi hedefleri doğrultusunda kullanmanın yollarını araması muhtemeldir.

\section{2 Çapraz Cihaz Hedefleme (Cross device targeting)}

Çapraz cihaz hedefleme, bir kişi hakkında ‘kullanıcı odaklı bir görüş elde etmek ve onları farklı cihazlar üzerinden hedeflemek üzere gittikçe - hem olasılıksal hem de belirlemeci - çok yönlü yollar geliştirmektedir.

Kampanya çalışmalarında bu teknolojiden halihazırda yararlanılmaktadır. Martin Moore'un siyasal kampanya çalışmalarında dijital pazarlamanın rolü üzerine gerçekleştirdiği araştırma, 'çapraz cihaz hedeflemenin siyasi girişimler ve diğer kampanyalar için artık standart bir prosedür haline geldiğini' ortaya koymaktadır. Moore ve Tambini 2018)'e göre siyasal kampanyalarda 'profil çıkarma ve segmentasyon her zaman yer almış olsa da, hızlı yeniliklerin birey düzeyinde hedeflemeyi çok daha etkili ve çok yönlü hâle getirdiğini' doğrulamaktadır. Örneğin Demokratik Ulusal Komite, seçmen dosyasını belli kişilere yönelik video reklamları, adreslenebilir TV spotları, mobil ve bilgisayar ortamında sunulan görüntüleme esaslı reklamlar için kullanılabilecek verilere dönüştürmek için veri hizmetleri firması Experian ve siyasi veri şirketi TargetSmart Communications ile çalışmıştır (Kaye, 2016). Bu, kampanyaların bireyleri mesajları almaya daha açık olabilecekleri belli zamanlarda, belli cihazlar üzerinde hedeflemelerine gittikçe daha fazla imkân sağlamaya başlamıştır (Schuster, 2015). Sektörün önde gelen çapraz cihaz pazarlama şirketi Drawbridge 2016 yılında 'Seçmen Merkezli Çapraz Cihazlı Hikâye Anlatıcılığı', 'Siyasi Etkileyen Tanımlama' ve 'Gerçek Zamanlı Seçmen Özellikleri Ölçümü' gibi uygulamalar aracılığıyla, kampanyalara seçmenleri etkilemenin çok sayıda yolunu sağlayan bir dizi hizmeti piyasaya sürmüştür (Chester ve Montgomery, 2017). Bu yolculuğun, gittikçe daha fazla müşteri segmenti üzerinden seyredeceği açıktır. Şirketler ve pazarlama uzmanları, hedef kitlelerine çok sayıda kaynaktan elde ettikleri veriler temelinde, farklı cihazlar üzerinden ve gittikçe daha fazla bireysel 
ve kişiselleştirilmiş yöntemlerle ulaşmanın yollarını aramaktadır. Michael Schneider bu kavrama 'yerlerden çok kişilere yönelme yaklaşımı' adını verir (Schuster, 2015). Bir pazarlama şirketi, Stirista, potansiyel destekçiler ve seçmenler olabilecek kişileri tespit etmek için siyasal pazarlamacılara ısmarlama hizmetler sunmaktadır. Stirista, internet sitelerinde yeni statükoyu şöyle açıklamaktadır: ‘günümüzde çevrimdışı ve çevrimiçi ortamlarda seçmenler ve bağışçılarla ilgili çok fazla bilgi mevcuttur. Kayda değer bir eyleme yol açacak bir mesajla her bir bireye ulaşabilmeniz için milyonlarca kaydı keskin, çok boyutlu, kişisel profillere dönüştürmek bile daha yeni bir teknolojidir.> Stirista (2019), 155 milyon kayıtlı seçmeni 'e-posta adresleri, çevrimiçi çerezleri ve sosyal medya hesaplarını kullanma biçimleri' ile eşleştirdiklerini ve intiyaç duyduğunuz doğrulukta profilleri oluşturmak üzere demografik, coğrafi, kültürel ve ilgi alanlarına dayalı verileri bir araya getiren 400 segmentasyon filtresine sahip olduklarını iddia etmektedir. Şirketin bir diğer iddiası, sahip oldukları çok yüksek sayıdaki irtibat bilgilerinin, isim ve nedenlerle birlikte son on yıla ait bağış geçmişini içerdiğidir. Bu alandaki bir başka gelişme, kişileri sosyal medya platformları üzerinden tek tek hedeflemek amacıyla coğrafi konum belirleme verilerinin uygulanmasıdır. Böylece partiler, örneğin, bir eylem veya etkinlikte yer alan kişileri tespit edebilmektedir. El Toro adlı şirket, bir etkinlikte bulunan cihazların listesini çıkarabildiğini, sonrasında bu cihazları, cihazın ev adreslerinin haritalandırılması yoluyla, IP üzerinden hedefleme uygulaması gerçekleştirebildiklerini iddia etmektedir. Bu uygulama, kampanyaların seçmenlerine evlerinde ulaşmalarına, kapı kapı dolaşarak oy avcılığı çalışmalarında irtibata geçemedikleri kişilere istenen mesajı iletmelerine imkân sağlamaktadır (Caswell, 2018). Yukarıda da belirtildiği gibi, coğrafi konum tabanlı hedefleme çalışmalarında ulaşııması beklenen önemli iyileştirmeler sonrasında bu yaklaşımın çok daha etkili hale gelmesi muhtemeldir.

Çapraz cihaz takibi, daha büyük bir trendin parçasıdır: sesli asistanlar ve egzersiz takip uygulamalarından akıllı çamaşır makinelerine kadar çeşitlilik gösteren ev loT (Nesnelerin İnterneti) cihazları, 'zoraki dinleyicilere erişim sağlamanın yeni yollarını yaratmaktadır (örneğin belli bir ürün kullanılmasını gerektiren bir ev işini tamamlamaya çalıştığı anlaşılan kişiler, bu profil üzerinden değerlendirilir ve hedeflenir). Bu aşamada IoT (Nesnelerin İnterneti) reklamcılığından yararlanan siyasi parti örnekleri yoksa da, potansiyel seçmenlerle yeni ve yenilikçi yollar üzerinden iletişime geçmek için rekabet eden siyasal kampanya uzmanlarının bu gibi tekniklere yönelmesi muhtemeldir.

\section{3 'Psikografik' veya Benzer Tekniklerin Kullanımında Artıș}

Kişilik testlerinin siyasi amaçlarla kullanılmasının uzun bir geçmişi vardır. Örneğin İkinci Dünya Savaşından sonra, Birleşik Devletlerdeki endişeli psikologlar, kimlerin faşizme yatkın olabileceğini belirlemek amacıyla 'F-ölçeğini geliştirmiştir' (Authoritarian Personality, 2017). Bu psikografik analiz şimdi büyük veride temellendirilmiştir ve çok sayıda reklam şirketi, tüketicilere (ya da seçmenlere) sosyal medyadaki varlıklarında gösterdikleri 'duygulara' göre ulaşma imkânı sunmaktadır. Siyasal kampanyalar için Experian Pazarlama Hizmetleri, seçmenleri dijital ortamda hedef almak için demografik, psikografik ve tutumsal özellikleri tek bir örüntüde bütünleştiren veriler sunmaktadır. Şirket, sundukları veriler sayesinde kampanyaların, bireylerin 'tutumları, beklentile- 
ri, davranışları, yaşam tarzları, satın alma davranışları ve medya tercihleri' aracılığıyla hedef kitlelerinin 'zihnini ve kalbini' inceleme şansına sahip olduklarını iddia etmektedir (Chester ve Montgomery, 2017).

Siyasi partiler, seçmenleri belli bir adaya oy vermeye teşvik etmek için ikna edici iletişim tekniklerine başvurmaya devam etmektedir. Bunlara OCEAN testi gibi özel kişilik testi tekniklerinin sınırı şekilde kullanımı da dahil olmuştur. Fakat bu yaklaşımın ne ölçüde işe yaradığına dair sağlam bir kanıt yoktur. Diğer yandan, yeni veri setlerinin artması ve bu yeni verilerin psikografik modellemeye entegre edilmesi sonucunda, kişilik tipleri ve duygu durumları hakkında yeni kavrayışlara ulaşılabilmektedir. Bu yaklaşım, bir insan analiz uzmanının tahmin etmesinin güç olduğu, fakat siyasal reklamcılık için kullanılabilecek derin öğrenme sistemlerinden elde edilen korelasyonlara dayanmaktadır. Bu tekniklerin ticari mecralara uygulanması geliştirilirse, partiler ve kampanya gruplarının bu teknikleri stratejilerine dahil etmeye devam etmeleri muhtemeldir. Ancak ticari bir bağlamda işe yarayan bir şeyin, siyasal kampanyalara kolaylıkla uyarlanabileceğinin bir garantisi olmadığı unutulmamalıdır.

Teknolojinin siyasal kampanya yürüten kişilere bireyin şahsi bilgilerini sunmasını sağlayabilecek unsurlardan biri de seçmenin ruh halidir. Yukarıda da açıklandığı gibi, L2 gibi veri şirketleri, bir seçmenin göç ve silah kontrolü gibi kutuplaşmaya yol açabilecek konularla ilgili görüşleri üzerine ayrıntılı veriler sunmaktadır - yani partiler, bireyin hangi politik endişelere sahip olabileceği ile ilgili kesin bir kontrol listesi oluşturabilir. Örneğin, politika değişiklikleri ile ilgili mesajlara daha açık olabilecek memnuniyetsiz yurttaşları tespit etmek için, araştırmacılar tarafından geliştirilmiş, bir kullanıcının 'yaşam memnuniyetini' çevrimiçi kaynaklardan ölçmeye yönelik yöntemlere başvurulabilir (Chen vd., 2017). Ya da sosyal medya paylaşımlarını, ısınma faturaları, egzersiz takip uygulamasının sağlık verileri bir araya getirilerek, her bir kullanıcının siyasal hayal kırıklıklarını ya da arzularını ortaya çıkarmak, sonra bu bilgiler üzerinden reklamların içeriğini belirlemek mümkün olabilir. Bu teknolojinin günümüzde siyasal kampanyalarda kullanıldığı bir örnek yoksa da kampanyalar ayrıca yüz tanıma teknolojisinin kullanılabileceği potansiyel bir alan durumundadır. Ancak bu teknoloji kamusal alanda kullanımı yaygın hale gelecek olursa, partiler benzer tekniklere - televizyon reklamlarını ve siyasal tartışmaları izleyen insanların yüz ifadelerini analiz edip, mesajları üzerinde buna göre ince ayarlar yapmak gibi - başvurabilecektir.

\subsection{Kampanyalarda Yapay Zekâ Kullanımı}

Siyasal kampanyalarda Yapay zekâların yakın gelecekte insan strateji uzmanlarından daha yüksek performans sunacakları tahmin edilebilmektedir. Böyle bir sistem, çok sayıda farklı kaynaklardan alınan büyük miktarda veriyi toplayıp, insan analistlerinin ayırt etmesinin mümkün olmadığı ilişkileri tespit edebilecektir. Yapay zekâ temelli platformların siyasal kampanyaları yarı-otonom bir şekilde yürütmesi, yakın gelecek için varsayılabilecek bir durumdur (Brundage vd., 2018). Bu teknolojiler, daha iyi hedefleme fonksiyonlarının yanı sıra, siyasal kampanyaların performansını iyileştirmek için kullanılabilir. Ticaret sektöründe, üreticilerin hangi mesajların daha yüksek tıklama oranları ya da daha fazla dönüşümle sonuçlandığını anlamalarına yardımcı olmak için 
reklamlar üzerinde gerçekleştirilen A/B testi yaygın bir uygulamadır. Bu yöntem, mesajı iyileştirmek ve hedef kitleye doğru şekilde yönelmek için, pazarlama kampanyası boyunca tekrarlanarak uygulanır. Hedef kitle segmentasyonu ve çapraz cihaz hedeflemede kaydedilen gelişmeler yoluyla, özel mesajlar, özel hedef kitlelerle test edilebilir. Etkili ve potansiyel seçmenlerde karşılık bulan mesajları tespit etmek, uzun süredir bu alanda faaliyet gösteren kişileri meşgul eden bir sorundur. Ancak bu yöntem, yakın zamana kadar her biri tecrübeli siyasetçiler tarafından ayrıntılı bir şekilde incelenip onaylanan sınırlı mesajların statik ve genel 'odak grupları' üzerinde test edilmiştir (Moore ve Tambini, 2018). Sosyal medyanın ve ticari reklam tekniklerinin kullanımı, bu girişimin tempo ve ölçeğine kademe atlatmıştır. Moore ve Tambini (2018), 'mesajların ideolojik veya siyasi tercihler değil, hedef kitlede karşılık bulması temelinde seçildiği' 'dinamik' bir süreçten bahsetmektedir. Facebook tarafından geliştirilmiş, bir reklamın önceden tanımlanmış tasarım özellikleri dizisinden yararlanan Dynamic Creative gibi araçlar, şimdiden bir reklamın binlerce farklı varyasyonunu oluşturmakta, kullanıcılara sunmakta ve katılım metrikleri üzerinden en uygun kombinasyonları bulmaktadır. Trump'ın dijital kampanya yöneticisi Brad Pascale'in CBS 60 Minutes'e verdiği röportajda bahsettiği özellik budur. Pascale, ekibinin günde 50.000 ile 60.000 arasında reklam varyasyonunu denediğini iddia etmiştir (McCandless Farmer, 2017).

\subsection{Otomatik İçerik Üretimi İçin Yapay Zekânın Kullanılması}

Son yıllarda Yapay Zekâ alanında yaşanan en önemli gelişmelerden biri, otomatik içerik üretiminin mümkün hale gelmesi, kampanyaların hedef kitlelerini ikna etmek için özel olarak geliştirilmiş, programlanabilir şekilde oluşturulmuş mesajlardan yararlanma imkânına sahip olmasıdır. İlgi alanları ve kaygıları hakkında sahip olunan bilgiler temelinde, her bir kullanıcıya otomatik olarak içerik üretebilmek için, algoritmik hedeflemenin yanı sıra Doğal Dil Üretimi araçlarından yararlanılabilir. Bu durumda bir sistem, alanda katılım ölçümleri aracılığıyla en uygun tasarım özellikleri kombinasyonunu bulmaya çalışmak yerine, hakkında en çok konuşulan konulardan [Trending Topic], kişisel verilerden ve bu öğeler arasındaki etkileşimin anlaşıımasından yararlanarak ısmarlama ve ince ayrıntılardan oluşan içerik üretebilir. Bu gibi kampanyalar, daha önceki etkileşimleri ya da yeni oluşturulmuş içerik parçaları ile ilgili olarak belirtilmiş endişeleri referans alarak karşılıklı etkileşime dayalı reklamlar tasarlamak üzere sohbet robotlarının etkileşimsel yönünü kişisel verilerle birleştirebilir. Bu mantık doğrultusunda, her bir seçmene yönelik benzersiz, kişiselleştirilmiş, A/B testleri aracılığıyla sürekli güncellenen bir mesaj akışı oluşturulabilir. Bu teknoloji şimdiden, alışveriş asistanları olarak görev alan ya da sosyal medya üzerinde gizlice insan taklidi yapan ticari sohbet robotIarının kullanımıyla uygulanabilmektedir. Özellikle sözlü makine-insan iletişiminde sohbet teknolojisi geliştikçe, bir sohbet robotu ile konuşmak insanlara daha doğal gelecek ve daha kişiselleştirilmiş özellikle sahip olacaktır. Bu aşinalık durumu, kampanyalarda siyasete ilişkin soruları yanıtlamak için 7/24 yardım hatları ya da propaganda çalışmaları sırasında hızlı ve bilgilendirici yanıtlar sunmaya yardımcı olmaya yönelik kullanılan sohbet robotlarının siyasal iletişimde yer bulmalarını sağlayabilir. ABD 2016 Başkanlık Seçimlerinde kullanılmış olan tarafsız sohbet robotu HelloVote, bunun yaşadığımız zamana ait bir örneği olarak düşünülebilir. HelloVote, oy verme hakkına sahip seçmen- 
lerin seçim kayıtlarını yapmalarına yardım etmiş, kayıtlarını yapmış olup olmadıklarını kontrol etmiş ve eyaletlerinde gerekli kimlikleri almalarına yardımcı olmuştur. Kullanıcılar, mesajlaşma yoluyla iletişim kurmuşlar ve HelloVote sistemi ya da çevrimiçi seçmen kayıt formlarını doğrudan doldurarak ya da doldurulmuş formları teslim etmeleri için kullanıcılara göndermişlerdir (Hello!Vote, 2019). Bu kullanım biçiminin her yönüyle olumlu olabileceğini söylemek mümkün değildir. Yapay Zekâ tarafından oluşturulan içerikler, yanlış yönlendirme ve dezenformasyon amacıyla kullanılmış ve insanlar arasındaki diyaloglara son vermek üzere (hem özel, hem de devlet destekli) sosyal medya bot hesapları, çevrimiçi alanları yanlış bilgilerle doldurmuştur (Galley vd., 2018, s.7). Benzer şekilde, içerik üretmeye dönük teknolojilerin insanları yanlış yönlendirip bireylerde kafa karışıklığı yaratmak amacıyla kullanılması olasıdır. Gerçekçi görüntüler üreten, gerçek sesleri ve yüzleri taklit eden bu teknoloji, yanlış bilgilendirmeyi teşvik etme, siyasilerin skandal niteliğinde bir şey söyledikleri ya da yaptıklarında sahte 'kanıtlar' sunma potansiyeline sahiptir (Vincent, 2018).

\subsection{Seçim Sonuçlarını Tahmin Etmek İçin Kișisel Verilerden Yararlanma}

Siyasi partiler, seçim kampanyaları sırasında - genel sonuçlarla ilgili tahminlerde bulunmak, politikaların ve siyasi liderlerin halk tarafından nasıl karşılandığını değerlendirmek ve hatta seçmenleri endişelendiren önemli konuları tespit etmek amacıyla - anket çalışmaları gerçekleştirirler. Son yıllarda kampanyalar, insanların nelerle ilgili kaygı duyduklarını anlamak ve bunun üzerinden seçim sonuçlarını tahmin etmek amacıyla sosyal medya kullanımına yönelmiştir. Galley vd. (2018, s. 4) tarafından gerçekleştirilmiş bir çalışma, bir adayın kamuoyu anketlerindeki performansı ile sosyal medya platformlarında paylaşılan mesaj türleri arasında güçlü bir ilişki olduğunu ortaya koymuştur. Bu çalışmada elde edilen bulgulara göre, anketlerde daha yüksek sonuçlar elde eden adaylar, Facebook ve Twitter'da daha aktiftir ve rakipleri aleyhinde mesajlar iletmek ya da kendilerini savunmak için bu kanallardan daha fazla yararlanma eğilimindedir.

2017 yılında gerçekleştirilen bir çalışma, siyasi beğeni davranışı ile gerçek oy verme niyeti arasındaki ilişkiyi incelemiş ve siyasilerin halka açık Facebook hesaplarındaki paylaşımlarının beğenilmesinin, seçmenin niyeti hakkında tahmin yürütmek için doğru bir ölçüm aracı olarak kullanılabileceği sonucuna ulaşmıştır. İlginç bir şekilde, bu araştırma ile seçilen tek bir Facebook paylaşımının beğenilmesinin, seçmenin niyeti hakkında yüzlerce heterojen beğeni kadar fikir verebileceği çıkarımına varılmıştır (Albrechtsen vd., 2017). Yakın zaman önce gerçekleştirilen bir başka çalışmada 2016 yılı Birleşik Devletler başkanlık seçimlerinde atılan Tweetler incelenmiş ve ilgili tweetlerde aktarılan düşünceler ile seçim sonuçları arasında bir ilişki olup olmadığı anlaşılmaya çalışılmıştır. Araştırmacılar, Twitter verilerini Seçim Kurulu sonuçları ile karşılaştırdıktan sonra, çevrimiçi mecrada aktarılan düşüncelerin, gerçek oy sonuçlarının \% 66.7'si ile örtüştüğünü görmüştür (Agrawal ve Hamling, 2017, s.36). 


\subsection{Yeni Platformlar Üzerinden Mesaj Iletimi}

Dijital video, giyilebilir teknoloji ve sanal gerçeklik, kullanıcılara yönelik içerik iletiminin gittikçe daha önemli gelen biçimleri durumundadır. Bu, telefonlar ve diğer cihazlar üzerinde görüntülenmesi durumunda markalar ve pazarlama kampanyaları adına duygusal içerik iletiminin son derece etkili bir yolu olduğu düşünülen video formatı için özellikle geçerlidir. Bu nedenle Youtube, siyasi reklamlar için önemli bir platform haline gelmiştir. YouTube şirketi günümüzde seçmenlerin siyasi kararlarını yalnızca 'oturma odalarında' televizyon karşısında değil, televizyonlarında videoları izlerken yaşanan 'mikro-anlarda' verdiklerini iddia etmektedir (Chester ve Montgomery, 2017).

Video formatının gittikçe daha fazla rağbet görmesi, beraberinde bazı tehlikeleri de getirmektedir: 2017 yılının sonları, kampanya sahiplerinin bazı sözleri rakiplerinin ağzından çıkıyormuş gibi göstermesine yarayan yüz değiştirme, sahte yüz teknolojilerinin yükselişine tanıklık etmiştir. Yapay Zekâ ve güvenlik açısından doğurduğu tehlikeler üzerine yakın zaman önce yayınlanmış bir raporda aktarılan şu uyarı dikkat çekmektedir: 'Yapay Zekâ Sistemleri, örneğin, siyasetçilerin dehşet verici (aslında gerçek olmayan) şeyler söylediği yüksek kaliteli montaj videoların üretimini kolaylaştırabilir. Bu da 'yakın gelecekte Yapay Zekânın mümkün kıldığı yüksek kaliteli sahtecilik uygulamalarının, kanıt niteliğindeki video ve ses içeriklerinin "görmek inanmaktır" yönünü ortadan kaldırabileceği anlamına gelir (Brundage vd., 2018, s.6). Bu - elbette hakkında sahte içerik üretilen kişinin kişisel bilgilerinin kullanımını içermiyorsa - kişisel bilgilerle ilgili olarak doğrudan bir sorun niteliği taşımayabilir.

Şirketler, ürün ve hizmetlerini satmak için sanal ve artırılmış gerçeklik platformlarını kullanmaya başlarken, siyasi tartışmaları gündeme getirmeye yönelik Sanal Gerçeklik Kampanyalarında da bir artış söz konusudur. Yönetmen Alejandro Iñárritu'nun yakın zaman önce gerçekleştirdiği bir projede, Birleşik Devletler sınırından geçen Meksikalı göçmenlerin deneyimlerini canlandırmak için Sanal Gerçeklikten yararlanılmıştır. Toplumun dikkatini bu sosyal sorunlara çekme niyetiyle bu teknolojilere başvuran tek proje bu değildir (Fink, 2018).

Nesnelerin İnterneti (lot) cihazlarına - özellikle giyilebilir teknolojik araçlara - sahip olma oranlarındaki artış, özellikle konum verilerinin kullanımı ile birlikte düşünüldüğünde pazarlama için yeni bir büyüme alanı olarak görülmektedir. Bu teknoloji ticaret sektöründe henüz emekleme aşamasında olduğu için, siyasi kampanyalara yönelik olarak geliştirilmiş herhangi bir uygulama mevcut değildir. Ancak bu, gelecekte yaygın bir şekilde kullanılabilecek bir alan durumundadır.

Siyasi kampanyalar, sosyal medyada reklam çalışmalarının yanı sıra, geleneksel platformları da - özellikle televizyonu - yeni şekillerde kullanmaktadır. Televizyon verilerinin (set üstü cihazlar ve akıllı TV cihaz verileri) toplanması ve kullanılmasındaki artış, hedefe yönelik televizyon reklamcılığında kat edilen gelişmeleri hızlandırmaktadır (SpotX, 2016). Daha doğru reklamlar sunmak için veri komisyoncularından alınan, farklı kaynaklardan elde edilen demografik ve çok platformlu verilerle güçlendirilmiş anlık görüntüleme verilerinden yararlanan siyasal kampanyalar, bu teknolojinin kullanılması noktasında öne çıkmaktadır. Comcast, Cox ve Spectrum'a ait Birleşik Devletler kablolu televizyon reklam platformu NCC Media, set üstü cihazdan elde edilen bilgileri 
Experian ve diğer mecralardan toplanan verilerle birleştirerek potansiyel seçmenleri bu doğrultuda hedefleyen kampanyalar sunmaktadır (Chester ve Montgomery, 2017).

Günümüzde önemini hala koruması nedeniyle hedefli televizyon reklamcılığına daha fazla yer verilmektedir. İki tür televizyon reklamı vardır: Adreslenebilir reklam (bu reklam tipinde belli bireyler hedeflenir, yani aynı anda aynı kanalı izleyen iki kişinin her biri farklı reklamları görebilir) ve tahmini reklamlar (belli bir pazardaki herkes aynı reklamları görür, fakat belli şovlar sırasında gösterilen reklamlar, politik gruplar tarafından, kilit seçmenlerin bu programları izleyeceği yüksek olasılığına dayanılarak seçilip ayrılır). Konunun uzmanlarına göre adreslenebilir siyasal reklamlar, siyasal kampanyalar tarafından daha yaygın olarak kullanılmaktadır. Diğer yandan bu reklamlar daha maliyetlidir. Bunun sonucu olarak siyasal kampanyalar, belli başlı seçmen segmentlerinin hangi programları izlemelerinin muhtemel olduğunu anlamak için çeşitli veri kaynaklarını daha fazla birleştirme yoluna gitmektedir (Bennas, 2016). Bunun açık bir örneği olarak, Forbes yakın zaman önce yayınladığı bir yazıda, Deep Root Analytics gibi hizmetlerin, Trump adına yürütülen kampanyanın, Obamacare karşıtı seçmenler arasında popüler olduğunu, 'The Walking Dead' dizisinin ise göçmen yasalarının daha katı hale getirilmesi gerektiğini savunan seçmenler tarafından tercih edildiğini tespit etmesine yardımcı olduğunu bildirmiştir (Bertoni, 2016).

Barack Obama ve Bernie Sanders'ın seçim kampanyaları üzerinde çalışan analiz şirketi HaystaqDNA'nın Yönetim Kurulu Başkanı Ken Strasma, televizyon ortamında hedefleme çalışmalarını iyileştirmek için sosyal medya verilerinden yararlanmayı henüz tam anlamıyla başaramadıklarını şu sözlerle açıklamaktadır:

"Ne yazık ki mevcut durumda, kimliklerini eşleştirdiğimiz ve ayrıca adreslenebilir televizyon sahibi olan kişilerin sayısı, bunu uygulanabilir hale getirmek için çok düşük.'(Bertoni, 2016).

Ancak yakın geçmiş içerisinde alınan patentler, çapraz cihaz hedefleme alanında önemli ilerlemeler kat edildiğine işaret etmektedir. Örneğin Intel IQ'nun patentinde, birden çok çevrimiçi cihazdan derlenen kullanıcı profilleri temelinde bir televizyon reklamının hedeflenebildiği açıklanmaktadır. Bunu yapmak için, kullanıcı profillerinden yalnızca birinin set üstü cihazla (bir televizyonu bir sinyal kaynağına bağlayan cihaz) ilişkilendirilmesi gerekmektedir. Bu nedenle siyasal reklamcılığın karşı karşıya kaldığı mevcut sınırlılıkların gelecekte de devam etmesi öngörülmemektedir.

\section{Siyasal Kampanyaların Önündeki Temel Zorluklar}

Veri temelli yönelimlerle birlikte siyasal kampanya çalışmaların önündeki temel zorluklar konusu aşağıda aktarılmaktadır. Bu çalışmanın öncelikli noktası kişisel bilgilerin gizliliği ile ilgili riskler veya sorunlar olduğu için, bu trendlerin kampanyalar ve seçimler için faydalar ele alınmadığı gibi, çalışma - kötü niyetli aktörlerin değil - yasal ve meşru siyasi partilerin yararlanma yoluna gidebileceği yasal yöntemlerle sınırlandırılmıştır.

Kişisel Gizlilik: Veri kullanımı ve hedefleme uygulamalarındaki en son gelişmelerin sonucu olarak çok sayıda gizlilik riski ortaya çıkmıştır. Bunların bazıları, yeni tüketici teknolojilerinden kaynaklanacaktır. Kraliyet Mühendislik Akademisi tarafından yakın 
zaman önce yayınlanmış bir raporda, lot (Nesnelerin İnterneti) cihazlarının, bu cihazlar aracılığıyla toplanan verilerin analiz edilmesi yoluyla bir kişinin konumunun çok daha kolay bir şekilde tespit edilmesi mümkün olabileceği için gizlilik açısından özellikle yeni bir risk doğurduğu uyarısında bulunulmuştur (Royal Academy of Engineering, 2018). Bu risklerin büyük bir bölümü, siyasal kampanyalar özelinde olmaktan ziyade genellikle tüketici gizliliği ile ilgilidir. Fakat siyasal kampanya verileri, pazarlama ve reklamcılıkla aynı yolu kullanırsa, hem çapraz cihaz hedefleme hem de kişiselleştirmeye - siyasi mesajların her bir bireye özel olarak ulaştırılması hedefine - daha fazla yönelim olacaktır. Bunun sonucunda kampanyaların bireyler hakkında daha fazla kişisel veriler içermesi ve toplaması ile mesajlarının etkililiğini en üst seviyeye çıkarmak için mümkün olduğunca veri çeşitliliğine sahip olmaları teşvik edilecektir.

Kullanıcı rızası ve bilgisi: Veri kullanımı ve hedefleme uygulamaları karmaşık ve otomatik hale geldikçe, kullanıcıların verilerinin nasıl kullanıldığı ile ilgili net bir açıklama talep etmesi ve kişisel bilgilerini geri alma talebinde bulunmaları daha güç hale gelecektir. Bunun sonucunda bireylerin, partilerin, düzenleme organlarının ve kampanya gruplarının, toplanan verilerin nasıl kullandığını anlaması zorlaşacaktır. Hedefleme uygulamasının gerçekte kimin sorumlu olduğu kullanıcı tarafından her zaman anlaşılamayabileceği için, bu durum çapraz cihaz hedefleme uygulamaları için özellikle geçerlidir.

Uygunsuz profil oluşturma ve mesajlaşma: Otomatik olarak oluşturulan içerikler, önümüzdeki yıllarda siyasal kampanya çalışmalarının önemli bir parçası haline gelme potansiyeline sahiptir. Muhtemel senaryolardan biri, partilerin seçmenler hakkında elde ettikleri ya da elleri altında bulundurdukları veriler temelinde, her bir seçmen için özel içeriğin otomatik olarak oluşturulduğu Doğal Dil Üretimidir. Bu gelişme, siyasal kampanya içeriğinin de otomatik olarak üretilebileceği anlamına gelmektedir. Bu yöntemler, tekrarlı A/B test ve üretim çalışmalarına dayalı kesintisiz ve yoğun bir süreci, herhangi bir editörün kapasitesini aşacak ölçek ve tempoda içerik üretimini içerebilir. Bu da uygunsuz, gerçekleri yansıtmayan ya da ön yargılara dayalı reklamların ortaya çıkması ile sonuçlanabilir. Reklamcıı̆ğın bu biçiminin tüm örneklerinin yasa dışı olması gerekmezse de (fakat bazı durumlarda yasa dışı olabilir), varlığı, kamuoyunun siyasal kampanyaların düzenleyiciler tarafından adil bir şekilde yürütüldüğü yönündeki güvenini sarsabilir ve halkın siyasi partilere olan güvensizliğini artırabilmektedir.

Hesap Verme Sorumluluğu: Önümüzdeki 3-5 yılda en önemli trendlerden biri, mevcut son teknoloji yapay zekâ, Doğal Dil Üretimi ve kullanıcı hedefleme uygulamalarının daha fazla yaygın ve kullanıma açık hale gelmesi olacaktır. Algoritma tabanlı pazarlama tekniklerin yakın gelecekte tüm siyasi partiler tarafından kullanılabilir hale gelerek, binlerce, belki milyonlarca algoritmik olarak ayarlanmış mesaj üzerinden çalışmalar gerçekleştirmelerine imkân sağlayacaktır. Bu ölçek, gösterilen siyasal reklamları etkin bir biçimde izlemeye çalışan düzenleyiciler için yönetilemez nitelikte olabilir. Düzenleyicileri yüksek hacimli mesajların güvenilir bir şekilde kontrol edilmelerine imkân sağlayacak yöntemlerle saklanmasının ve daha geniş kitlelerle paylaşılmasının yolları üzerinde düşünmeleri önerilmektedir. Bu başarılmazsa, kampanyaların şeffaflığı ve politik hesap verebilirlik ile ilgili endişelerin artması riski söz konusudur. 
Duygusal manipülasyon: Birini manipüle etmek demek örtük bir biçimde onu etkilemek, kasıtlı bir biçimde karar verme süreçlerini değiştirmek ve bunu kişinin bilinçli farkındalığı olmadan yapmak anlamına gelmektedir. Bunu yapmak kişilerin özerkliğini de tehdit etmektedir; yani kendilerinin seçmemiş oldukları bir sonuca giden eylemlerde bulunmalarına yol açabilirler. Bir örnek olarak ticari alandaki hedefli reklamları ele alaIım. Bu noktada manipülatörlerin hedefi aslında son derece nettir; sadece insanların bir şeyler almasını isterler. Öte yandan reklamcılar sadece ürünleri vitrine koymaktansa, karar verme ortamları (seçim mimarileri) inşa etmekte, alışveriş yapanları da belli belirsiz biçimde bu ortamlar aracılığıyla, mümkün olan en yüksek fiyatlarla ürünlerini satın alma konusunda cezbetmeye çalışmaktadırlar (Calo, 2014'ten aktaran Suesser, Roessler ve Nissenbaum, 2019).

Duygusal manipülasyon aslında reklamcılık çevrimiçi hale daha dönüşmeden ortaya çıkmıştır. Örneğin, bir psikiyatrist reklamları depresyondan mustarip olduğundan şüphelenilen kişilere gösterilir ve bu sadece günün belirli saatlerinde, bu kişilerin durumunun en kötü olduğu saatlerde gerçekleştirilmekteydi. Sonuç olarak karar vermemizi yönlendirecek seçim ortamlarını kasıtlı ve örtük biçimlerde düzenleyen çevrimiçi manipülasyon kavramı, seçeneklerimiz üstüne düşünme, onlarla ilgili niyetler oluşturma ve bu niyetlere dayalı olarak eylemde bulunma yetkinliklerimizi tehdit etmektedir. Çünkü manipülasyon genellikle karar vermemizdeki zayıflıkları hedef alarak süreci suistimal ettiği ve bu şekilde işe yaradığı için, eylemlerimizin özgün bir biçimde kendimizin olduğunu doğrulama ve onlar üzerine uzun uzadıya düşünme kapasitelerimize de meydan okumaktadır; etkilerini saklarlar ve bizim karar verme süreçlerimiz üzerinde etkili olduklarının farkında bile olamayız. Çevrimiçi manipülasyon böylelikle bizi hem seçmediğimiz yollara giden eylemlere iterek hem de arkasında duramayacağımız nedenlerle bunu yaptırarak bize zarar vermektedir (Suesser, vd., 2019, ss. 9-11).

Konuya veri temelli olarak bakıldığında, çok büyük veri setlerinin oluşturulması ile birlikte psikografiden veya daha geniş kapsamlı duygusal hedefleme tekniklerinden yararlanma konusu ilerleme kat etmektedir. Hedefleme algoritmalarının çıkarımda bulunma gücünü artırmak amacıyla kişilik anket verilerinin Nesnelerin İnterneti cihazları, konum geçmişleri ve sosyal medyadan elde edilen çok daha büyük ve daha çeşitli veri setleri ile ilişkilendirilmektedir. Bu, kampanyaların kişilik tipleri / ruh halleri / psikolojik durumlar ile davranış kalıpları arasında ilişkiler kurmalarına yardımcı olmaktadır. Ayrıca reklamcılıkta tüketicilerin kişiliklerini yansıtan içeriklerden yararlanarak, onları alımlamaya en çok açık oldukları yer ve zamanda hedeflemenin yeni yollarının bulunmasına zemin hazırlamaktadır. Bu sürecin büyük bir kısmı otomatik olduğu için, Yapay Zekâ tabanlı bir sistem, siyasi partilerin bazen aşırı depresif, endişeli veya belli psikolojik sorunlardan mustarip kişileri hedef alması, reklamların onları cezbedecek şekilde tasarlanmasına yol açabilir. Bu, etik açıdan sorgulanabilir olmakla birlikte, bireysel hedefleme segmentasyon, keşfedilmesi durumunda kampanyayı yürüten siyasi partinin itibarına zarar verebilecektir. Genel olarak politik mesajların daha duygusal bir ton taşıması, seçmenleri harekete geçirip içerikle ilişki kurma amacıyla hedef kitlede öfke, hayal kırıklığı veya ön yargı oluşturabilir. Bunun sonucunda demokrasinin sağlığı üzerinde uzun vadeli başka zararlı etkiler de meydana gelebilecektir.

Bu etkilere son yıllarda yaşanan ve büyük bir psikolojik manipülasyon olarak adlandı- 
rılan ve dataların kötü amaçlarla kullanıldığı Cambridge Analytica ve Facebook hikayesini örnek göstermek mümkündür. 2014 yılında Cambridge Üniversitesi Profesörü Aleksandr Kogan tarafından ABD seçmeni hakkında ayrıntılı psikolojik profil çıkarmayı amaçlayan bir anket uygulaması geliştirildi ve bu uygulama o dönemde geliştirilen çoğu uygulama ve oyunun yaptığı gibi Facebook bilgilerinize erişim izni istiyordu ve bunu yaparken sadece sizin bilgilerinizi değil arkadaşlarınızın bilgilerini de sizin aracılığınızla topluyordu. Kogan, anket uygulaması için Amazon'un Mechanical Turk (MTurk) projesini kullandı ve bu proje aracılığıyla ankete katılan MTurk kullanıcılarına 1'er dolar ödeme yaptı. Daha önce Cambridge Analytica ile çalışmış olan Christopher Wylie tarafından paylaşılan bilgiye göre 270 bin kişinin katıldığı bu uygulama, arkadaş bilgilerini de toplayarak yaklaşık 50 milyon kişilik devasa bir kullanıcı bilgisi topladı ve bu uygulama tarafından toplanan tüm veriler Cambridge Analytica'ya satıldı. (Satış işlemi, datayı alıp satmak şeklinde değil de Kogan tarafından kurulan şirketin, Cambridge Analytica ile iş yapan bir başka şirketle anlaşması şeklinde gerçekleşti.) Psikolojik profil detaylarına sahip olduğu 50 milyon kişilik potansiyel seçmen datasını kendi elindeki verilerle birleştiren Cambridge Analytica, o dönemden itibaren birçok farklı başkan adayının kampanyasında bu dataları reklam hedeflemesi amacıyla kullanmaya başladı. Mark Zuckerberg, Kogan'ın verileri Cambridge Analytica'ya sattığı ortaya çıkınca bunun geliştirici anlaşmalarına aykırı olması dolayısıyla uygulamanın kaldırıldığı ve Cambridge Analytica'nın tüm verileri silmesi yönünde uyarıların yapıldığını söylemişti. Bunu sadece sözlü bir uyarı değil ve Cambridge Analytica, Facebook'a verileri sildiklerine dair sertifika sağladıklarını söylemişti. Yapılan anket detaylarına göre tek tek hangi kullanıcının verisinin bu uygulama aracılığıyla alındığını bildiği halde Facebook bu zamana kadar kullanıcılara hiçbir bildirim göstermedi, uyarmadı veya bilgilendirmemişti. Bu gibi çıkan haberlerin hemen ardından Facebook, Cambridge Analytica ile iş birliklerini sona erdirdiğini duyurmuştu (Anderson, 2018). 2015 yılında The Guardian tarafından da detaylı olarak paylaşılan bu konu Facebook'un yaşadığı bilinen en büyük kriziydi.

Sonuç olarak, bireylere zararın ötesinde, manipülasyon kolektif bir zararı taahhüt etmektedir. Özerkliğimizi tehdit etmek suretiyle, manipülasyon demokrasiyi de tehdit etmektedir. Özerkliğin küçük ölçekte buyurduğu şey, demokrasinin büyük ölçekte buyurduğu şey ile aynıdır: öz-yönetim kapasitesi. Bireylerin anlamlı bir biçimde bağımsız karar verebileceklerine inandığımız için bunları kaydedecek ve yansıtacak kurumlara değer veririz. Cambridge Analytica ve buna yanıt olarak gelen halkın feryadı, çevrimiçi manipülasyonun siyasi alanda da söz konusu temelde kolektif değerlerin göz ardı edilmekle tehdit edildiğini ortaya koymuştur (Suesser vd., 2019, s.11).

Rekabet: Çeşitli analiz uzmanlarına göre - özellikle Facebook ve Google gibi - bazı şirketler çevrimiçi reklamcılık açısından gittikçe baskın hale gelmektedir. İnsanları hedeflemeye yönelik hizmetlerinin sürekli iyileşmesi, kişisel asistanlar aracılığıyla gerçekleştirdikleri reklam çalışmaları ile insanların evlerine ulaşma kapasiteleri artmaktadır. Sonuç olarak bu şirketlerin seçimler sırasında yürüttüğü çevrimiçi reklam çalışmalar da daha önemli hale gelmektedir. Moore ve Tambini'nin bu konuda yaptıkları bir çalışmada belirttikleri gibi, 'özellikle şeffaf olmayan yabancı şirketlerin süregelen baskınlığı ve tekelci konumlarının güven, adalet ve meşruluk konularında aşındırıcı bir etkiye sahip olabilmektedir (Tambini, 2018). 
Kişisel verilerin yeni biçimlerinin yaratılması: Çıkarımsal veri oluşturma süreçlerinde (mevcut veri noktalarının analiz edilmesi üzerinden bir kullanıcı hakkında olasılıksal çıkarımlarda bulunulan süreçler) yaşanacak muhtemel gelişmeler, yeni veri kategorileri yaratacaktır. Örneğin mevcut trendler ile cihaz kullanımları, bilgi tarama alışkanlıkları vb.'den elde edilen meta verilerin çok yönlü analizleri temelinde bir bireyin cinsel tercihleri, siyasi görüş ve yönelimleri, oy verme geçmişi vs.'nin doğru bir şekilde belirlenmesi mümkündür. Bu sürecin yeterince isabetli hale gelmesi, özel bir şirketin, söz konusu bireyin bilgisi olmadan topladığı kişisel veriler üzerinden çıkarımlar yapmasını mümkün kılabilir. Bu konuda siyasal kampanyaları özellikle ilgilendiren, - ekonomi, göç, çevre gibi konular hakkındaki - belli mesajların 'ikna gücüdür' (Agrowal ve Hamling, 2017, ss. 36-41). Bu ikna gücü, kişinin siyasi görüşlerinin belirlenmesine yardımcı olmaktadır. Kullanıcının bu verilerin var olduğunu bilmesi, kaldırılmasını ya da başka şekillerde işlenmesini talep etme haklarından yararlanmasını güç kılmaktadır.

\section{Sonuc}

Siyasal kampanyalar, daha ayrıntılı seçmen profilleri elde etmek için yıllardır seçmen davranışına ilişkin kendi verilerini, veri aracılarının sunduğu ticari veri dizileri ile birleştirmektedir. Ayrıca çok sayıda firma, veri madenciliği ve seçmenleri hedefleme uygulamalarına destek sunmaktadır. Bu uygulamalar, çok çeşitli çevrimiçi ve çevrimdışı kaynaklardan bireyler hakkındaki verileri toplayıp analiz etmektedir. Toplanıp analiz edilen veriler, daha sonra 'reklam değişimi' sistemleri aracılığıyla ya da doğrudan büyük sosyal medya platformları üzerinden seçmenleri hedeflemek amacıyla kullanılabilmektedir.

Siyasal kampanyalarda ikna potansiyelini en üst seviyeye çıkarmak için kimin, ne zaman ve hangi içerikle hedeflenmesi gerektiğini çözümleme noktasında Yapay zekâların yakın gelecekte insan strateji uzmanlarından daha yüksek performans sunacakları tahmin edilebilmektedir. Böyle bir sistem, çok sayıda farklı kaynaklardan alınan büyük miktarda veriyi toplayıp, insan analistlerinin ayırt etmesinin mümkün olmadığı ilişkileri tespit edebilecektir. Yapay zekâ temelli platformların siyasal kampanyaları yarı-otonom bir şekilde yürütmesi, yakın gelecek için varsayılabilecek bir durumdur. Bu teknolojiler, daha iyi hedefleme fonksiyonlarının yanı sıra, siyasal kampanyaların performansını iyileştirmek için kullanılabilir.

Siyasal kampanyalarda yapay zekâyı kullanırken, daha önceki etkileşimleri ya da yeni oluşturulmuş içerik parçaları ile ilgili olarak belirtilmiş endişeleri referans alarak karşılıklı etkileşime dayalı reklamlar tasarlamak üzere sohbet robotlarının etkileşimsel yönünü kişisel verilerle birleştirilebilir. Bu doğrultuda, alışveriş asistanları olarak görev alan ya da sosyal medya üzerinde gizlice insan taklidi yapan ticari sohbet robotlarının kullanımıyla uygulanabilmektedir. Özellikle sözlü makine-insan iletişiminde sohbet teknolojisi geliştikçe, bir sohbet robotu ile konuşmak insanlara daha doğal gelecek ve daha kişiselleştirilmiş özellikle sahip olacaktır. Tüm bunlarla birlikle siyasal partiler seçimlerin sonuçlarıyla ilgili tahminlerde bulunurken politikaların ve siyasi liderlerin halk tarafından nasıl karşılandığını değerlendirmek ve hatta seçmenleri endişelendiren önemli konuları tespit etmek amacıyla kişisel verilerden yararlanmaktadırlar. Yapılan 
araştırmalar ise seçmenlerin politik olarak en çok paylaşım yaptıkları platformların en çok Facebook ve Twitter olduğunu göstermiştir.

Yeni iletişim teknolojilerinin gelişimiyle seçmenlere içerik iletimi de gittikçe değişmiştir. Gazete-dergi reklamları, broşür veya açık hava reklamları yerini dijital video, giyilebilir teknoloji ve sanal gerçeklik gibi uygulamalara bırakmıştır. Özellikle Youtube, siyasi reklamlar için önemli bir platform haline gelmiştir. Ancak bu gibi platformların yaygınlaşması beraberinde bazı tehlikeleri de getirmektedir. Çünkü Yapay Zekâ aslına benzer, sahte uygulamalarla kötü niyetli aktörlerin oluşumuna zemin hazırlayabilmektedir. Bu - elbette hakkında sahte içerik üretilen kişinin kişisel bilgilerinin kullanımını içermiyorsa - kişisel bilgilerle ilgili olarak doğrudan bir sorun niteliği taşımayabilir. Bu çalışmanın öncelikli konusu kişisel bilgilerin gizliliği ile ilgili riskler veya sorunlar olduğu için, çaIışma, kötü niyetli aktörlerin değil - yasal ve meşru siyasi partilerin yararlanma yoluna gidebileceği yasal yöntemlerle sınırlandırımıştır. Bu bağlamda veri kullanımı ve hedefleme uygulamalarındaki en son gelişmelerin sonucu kişisel gizlilik açısından risk oluşturmaktadır. Çünkü kişinin konumunun çok daha kolay bir şekilde tespit edilebilecektir. Büyük veri ve algoritma teknolojileri çoğunlukla karmaşık, Yapay Zekâ odaklı işlemlerin ise irdelenmesi ve açıklanması genel olarak zor olduğu için, 'bilgilendirilmiş rıza' prensibinin, veri işlemenin 'gündelik' biçimlerine uygulanması gittikçe zorlaşacaktır.

Çalışma sonucunda algoritma tabanlı pazarlama tekniklerin tüm siyasal partiler tarafından kullanılacağını öngörmekle birlikte, içeriklerin kontrol edilme sorunu ortaya çıkacaktır. Böylece siyasi parti ve liderlerin hesap verebilme sorumlulukları risk altına girecektir. Hedef kitle segmentasyonunun keşfedilme olasılığı ise siyasal partilerin itibarını olumsuz yönde etkileyecektir.

İletişim teknolojilerindeki gelişmelerle yeni kampanya düzenlemeleri de gerekmektedir. Duygusal manipülasyon gibi bireylerin kişisel verilerini kullanarak çıkarlarını tehdit ettiği uygulamalar oldukça tartışmalıdır. Çünkü bilinçli farkındalık halinin dışında yönlendirilmek veya kontrol edilmek, özerkliği ve bireylerin kendi hayatını ihlal etmektedir. Eğer böyle bir kontrolü kolaylaştıran araçlar denetimsiz kalırsa, hem bireysel hem de kolektif olarak zarar görülmesi olasıdır. Gelişen bilgi teknolojileri aynı zamanda bu zararı önleyecek kontrol biçimlerini de sağlayacak bir araçtır. Dolayısıyla bu gibi konularla baş edebilmek; bireyleri etkilemeye çalışan güçlere karşı farkındalık, anlayış ve bilgi ile donatmak gerekliliklerini de beraberinde getirmektedir.

Türkiye'de Kişisel Verileri Koruma Kanunu 2016 yılında yürürlüğe girmiştir. Devletin yasal yolla verileri korumaya çalışıp politika üretmesi önemli ancak tek başına yeterli değildir. Çünkü politikanın oluşması ve verilerin korunması yönünde sanal ortamda mahremiyet kültürünün oluşması, kullanıcıların hangi veri korunmalı sorusuna yanıt verebilecek ve bu ayrımı yapabilecek düzeyde bilgi sahibi olmasını gerektirir.

Sohbet robotları kampanyalarda siyasete ilişkin soruları yanıtlamak için 7/24 yardım hatları ya da propaganda çalışmaları sırasında hızlı ve bilgilendirici yanıtlar sunmaya yardımcı olmalıdırlar. Robotlar ancak bunu tanımlanmış otomatik içerikten tarayarak seçmenin sorduğu soruya yönelik cevap verirse etik ilkeler çerçevesinde gerçekleştirmiş olur. Yapay Zekâ tarafından oluşturulan içerikler, yanlış yönlendirme ve dezenformasyon amacıyla kullanılacak olabilir. Benzer şekilde, içerik üretmeye dönük 
teknolojilerin insanları yanlış yönlendirip bireylerde kafa karışıklığı yaratmak amacıyla kullanılması olasıdır. Gerçekçi görüntüler üreten, gerçek sesleri ve yüzleri taklit eden bu teknoloji, yanlış bilgilendirmeyi teşvik etme, siyasilerin skandal sayılabilecek konularda sahte 'kanıtlar' sunma potansiyeline sahiptir. Bu amaca yönelik kullanımlarda, vatandaşların teknoloji alanındaki yeterliliğin ne olması gerektiği sorunsalı ile karşı karşıya kalınmaktadır. Buna göre dijital becerileri oluşturan çeşitli yetkinliklere göre ulusal ölçekte politika yapıcılar, global ölçekteki gelişmeleri de izleyerek dijital becerilerin öğretim programları ile daha etkili şekilde bütünleştirilmesini sağlayacak çalışmalar ortaya koyabilirler. Bölgesel ölçekte yönetici ve idareciler okullarında dijital becerilerin öğrencilere daha etkili şekilde kazandırılması yönünde adımlar atabilirler.

\section{Kaynakça}

Agrawal A. ve Hamling T. (2017). Sentiment Analysis of Tweets to Gain Insights into the 2016 US Election. Columbia Undergraduate Science Journal, Volume 11. 34-42.

Albrechtsen T. Vd. (2017). Parsimonious data: How a single Facebook like predicts voting behavior in multiparty systems. 12 Kasım 2019 tarihinde http://journals.plos.org/ adresinden edinilmiştir.

Anderson M. (2018). Facebook privacy scandal explained. 07.05.2020 tarihinde https://www. ctvnews.ca/sci-tech/facebook-privacy-scandal-explained-1.3874533 adresinden edinilmiştir.

Authoritarian Personality (2017). Psychologist world. 12 Ağustos 2019 tarihinde https://www. psychologistworld.com adresinden edinilmiştir.

Bennas, R. (2016). Targeted TV ads find niche in political campaigns. 29 Ağustos 2019 tarihinde https://digiday.com/media/targeted-politics-ads/ adresinden edinilmiştir.

Bertoni S. (2016). Exclusive Interview: how jared kushner won trump the white house. 14 Temuz 2019 tarihinde www.forbes.com adresinden edinilmiştir.

Brundage M. vd. (2018). The malicious use of artificial Intelligence: forecasting, prevention, and mitigation. 20 Ocak 2020 tarihinde https://arxiv.org/ttp/arxiv/papers/1802/1802.07228.pdf adresinden edinilmiştir.

Cadwalladr C. (2017). British Courts may unlock secrets of how Trump campaign profile US voters. The Guardian. 5 Ekim 2019 tarihinde https://www.theguardian.com adresinden edinilmiştir.

Caswell, K. (2018) Three political marketing strategies: using el toro for digital advertising political marketing strategies. 10 Aralık 2019 tarihinde https://www.eltoro.com/politicalmarketing-strategies/ adresinden edinilmiştir.

Chen L. vd. (2017). Building a profile of subjective well-being for social media users. PLoS.

ONE 12 (11): e0187278. (11-15).

Chester J ve Montgomery K. (2017). The role of digital marketing in political campaigns. Internet Policy Review. 6(4). 1-20.

Constine J. (2016). Hustle is the grassroots personalized mass-texting tool we need. 28 Aralık 
2019 tarihinde: www.techcrunch.com adresinden edinilmiştir.

Dobber T. Vd. (2017). Two crates of beer and 40 pizzas: the adoption of innovative political behavioural targeting techniques. Internet Policy Review. 6(4). 1-25.

Fink C. (2018). Inarritu's VR Hit 'Carne y Arena' Storms DC. 8 Ocak 2020 tarihinde https://www. forbes.com adresinden edinilmiştir.

Galley J. vd. (2018). Social Media, U.S. presidential campaigns, and public opinion polls: disentangling effects. AolR Selected Papers of Internet Research. 6. 2 Eylül 2019 tarihinde https:// journals.uic.edu/ojs/index.php/spir/article/view/8870 adresinden edinilmiştir.

Grunig J. ve Repper F. (2005). Stratejik Yönetim Kamular ve Gündemler, Grunig (Der.). (s.129169) içinde, Halkla İlişkiler ve İletişim Yönetiminde Mükemmellik, İstanbul: Rota Yayınları.

Hwang H., Jung T., Suh E. (2004). An LTV Model And Customer Segmentation Based On Customer Value: A Case Study On The Wireless Telecommunication Industry, Expert System with Applications, 26. 181-188

Hello! Vote. 24 Aralık 2019 tarihinde https://www.hello.vote/ adresinden edinilmiştir.

Kaye K. (2016). RNC's voter data provider teams up with Google, Facebook and other Ad firms. 27 Aralık 2019 tarihinde http://adage.com adresinden edinilmiştir.

Kotler P. ve Armstrong G. (2001). Principles of Marketing, Prentice Hall, New Jersey, 245-256.

L2 Voter File Enhancement. 12 Haziran 2019 tarihinde http://www.l2political.com adresinden edinilmiştir.

McCandless Farmer B. (2017). Who is brad parscale?. 2 Ekim 2019 tarihinde https://www. cbsnews.com/news/who-is-brad-parscale/ adresinden edinilmiştir.

Royal Academy of Engineering (2018), Internet of things: realising the potential of a trusted smart world. 24 Kasım 2019 tarihinde https://www.raeng.org.uk/publications/reports/internet-of-things-realising-the-potential-of-a-tr adresinden edinilmiştir.

Schuster J. (2015). Political Campaigns: The art and science of reaching voters. 22 Ekim 2019 tarihinde https://liveramp.com adresinden edinilmiştir.

Sim Machines (2018), Dynamic predictive segmentation is the future of marketing. 3 Ocak 2020 tarihinde https://simmachines.com/ adresinden edinilmiştir.

SpotX (2016). The definition and future of audience data and audience targeting. 17 Ekim 2019 tarihinde https://www.spotx.tv/resources/blog/product-pulse/the-definition-and-future-of-audience-data-and-audience-targeting/ adresinden edinilmiştir.

Steward H. (2017). Labour takes to the streets and social media to reach voters. The Guardian, 2 Eylül 2019 tarihinde https://www.theguardian.com adresinden edinilmiştir.

Stirista (2019). Political Marketers. 2 Şubat 2020 tarihinde https://www.stirista.com/who-weserve/political-marketers adresinden edinilmiştir.

Susser, D., Rooesler, B. ve Nissenbaum, H. (2019). Technology, Autonomy and Manipulation. Internet Policy Review (8)2. 1-22. 
Tambini D. (2018). Social Media Power and Election Legitimacy. D Tambini ve M Moore (Der.) Digital dominance: The Power of Google, Amazon, Facebook, and Apple içinde Oxford University Press.

Ungerlieder N. (2015). Facebook unveils advertising for "political Influencers. 18 Temmuz 2019 tarihinde https://www.fastcompany.com adresinden edinilmiştir.

Vincent J. (2018). Watch Jordan Peele use Al to make Barack Obama deliver a PSA about fake news. 18 Aralık 2019 tarihinde https://www.theverge.com adresinden edinilmiştir.

Waterson J. (2017). Here's How Labour Ran An Under-The-Radar Dark Ads Campaign During The General Election. 2 Ağustos 2019 tarihinde https://www.buzzfeed.com/ adresinden edinilmiştir.

Windsor G. ve Murphy S. (2014). Big data and the 2015 UK General Election: digital democracy or digitally divisive?. 2 Temmuz 2019 tarihinde https://www.nesta.org.uk adresinden edinilmiştir.

Yovanno D. (2018). Marketing technology is transforming the way brands work with influencers. 2 Ocak 2020 tarihinde http://www.adweek.com adresinden edinilmiştir. 